\title{
ANALYSIS OF THE EFFECT OF PROFITABILITY AND LIQUIDITY ON INCOME MANAGEMENT WHICH IMPACT ON COMPANY VALUE IN SOE BANKS REGISTERED ON INDONESIA STOCK EXCHANGE PERIOD 2009- 2019
}

\section{Masno Marjohan}

Pamulang University Graduate Lecturer, Banten, Indonesia

Email: masnomarjohan@yahoo.co.id

\begin{abstract}
This study aims to analyze, test the effect of profitability as measured by Return On Assets, liquidity as measured by LDR on earnings management, and the impact of earnings management on firm value in state-owned tire companies listed on the Indonesia Stock Exchange from 2009 to 2019. Total population This research is 4 state-owned bank companies so that the entire population is sampled with a period of 10 years from 2009-2019. The analysis technique used in this research is panel data regression to obtain a comprehensive picture of the relationship between one variable and another. The results of the research partially show that ROA, LDR Profitability has no effect on Earning Management, Profitability and Liquidity simultaneously have an effect on Earnings Management, and show that earnings management affects Firm Value.
\end{abstract}

Keywords: Profitability; Liquidity; Earnings Management Dan Firm Value

Coresponden Author

Email: masnomarjohan@yahoo.co.id Article with open access under license

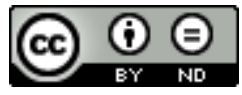

\section{Introduction}

Banking institutions are one of the backbone of a country's economy, because it has the function of intermediation or as an intermediary between the owner of capital (fund supplier) and the fund user. Banks with healthy financial performance are an important goal, so that the intermediation function can run smoothly. The monetary crisis, which has been going on since mid-1997, has resulted in a severe banking crisis in Indonesia. This condition prompted the restructuring of banking. (Gerdes, Trinugroho, Fensli, \& Lilletunsvei, 2013) The main role of the bank is as a financial intermediary institution, which is to divert funds from the surplus to the underfunded party (deficit) in addition to providing other financial services. Reviewed in terms of ownership, banks are grouped into government banks and private banks. Government banks have a dual role, namely profit oriented and social oriented agents. Therefore state 
banks have an obligation to be able to manage state assets properly. Currently, there are four government-owned banks or known as STATE-owned banks in Indonesia that have gone public, namely Bank Negara Indonesia (BNI), Bank Rakyat Indonesia (BRI), Bank Tabungan Nasional (BTN), and Bank Mandiri (www.bi.go.id).

Profit Management is the price that prospective buyers are willing to pay if the company is sold, the higher the Profit Management the greater the prosperity that will be received by the owner of the company (Husnan \& Pudjiastuti, 2012). If the financial performance shows good prospects, then the stock will be in demand by investors and affect the selling value of the stock.

A company's performance can be assessed using financial statements. Financial statements are the basis for calculating financial ratios. Analysis of financial ratios can reveal important relationships and form the basis of comparison in finding conditions and trends that are difficult to detect by studying each component that makes up the ratio (Subramanyam \& Wild, 2013). The bank's financial performance indicators differ from those of the company's performance. The bank's financial performance measurement stipulated in Bank Indonesia's Circular Letter (SE). For external parties, especially creditors and investors, financial ratios can be used in determining whether a company is reasonable to be given credit or to be used as a good investment land (Dewi \& Sari, 2015).

Profitability is expected to be one of the benchmarks in the company's valuation, because Return On Asset (ROA) is important in measuring the profitability of a bank, which describes a bank's ability to earn overall profit (Defri, 2012), supported by capital in increasing capital adequacy as presented by (Sudiyatno \& Suroso, 2010) there is a positive and significant influence between CAR against ROA and the power of liquidity in the form of LDR which should be good, because LDR reflects the main activity of a bank which can be interpreted as the level of lending also affects the amount of ROA value (Defri, 2012).

With the Average LDR bank soe has fluctuated downwards. The average LDR in 2006 was $69.17 \%$. In 2007 there was a decrease of $65.05 \%$ and ROA also decreased by $1.63 \%$, while in 2008 LDR increased by $77.31 \%$ while ROA decreased by $1.41 \%$ this is not in line with the theory that if LDR increases then ROA will also rise. In 2009 LDR decreased by $76.85 \%$ while ROA increased by $1.50 \%$. while in 2010 LDR increased by $78.04 \%$ and ROA only increased to $1.59 \%$ (Wibisono, 2013).

According to (Marelli \& Omenetto, 2015), Return on Assets is a ratio that shows the return on the amount of assets used in the company. There are several factors affecting Return on Assets including the level of turnover of assets in the company's operating activities and the amount of profit earned from the amount of net sales expressed in the form of percentages. 


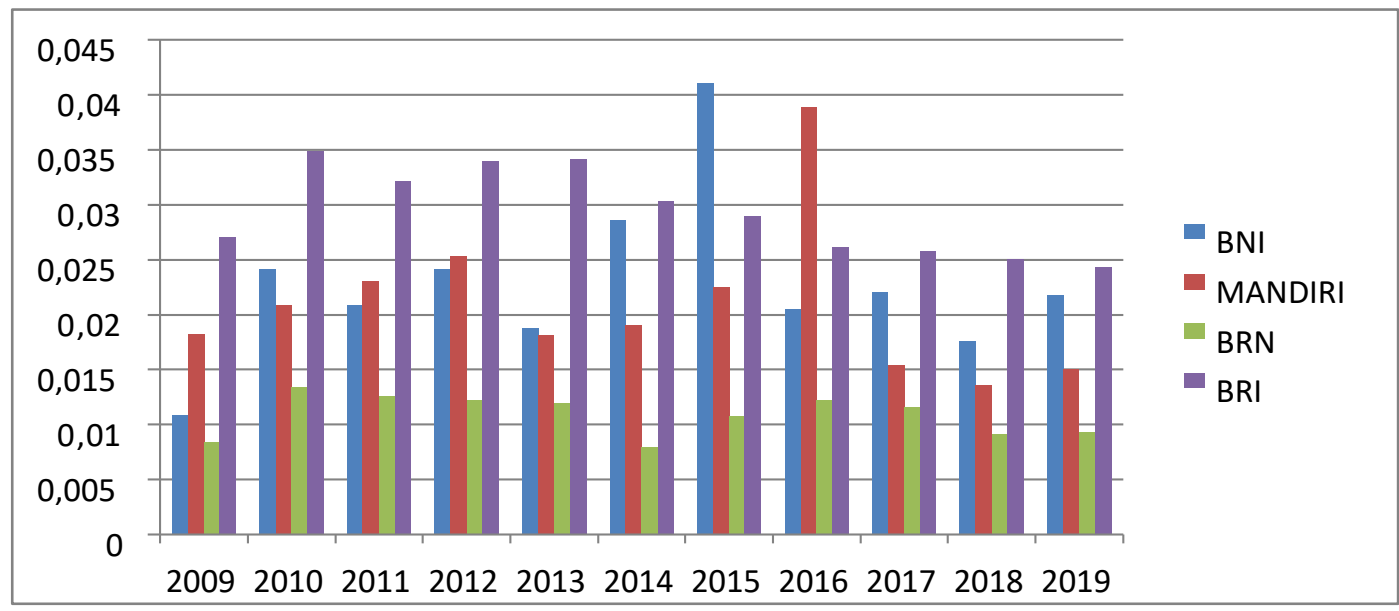

\section{Graph Figure 1}

Graph of SOE Banking Return on Assets Development for the Period of 2009-2019

Profitability that is measured by Return on Assets is very important in a company because by knowing Return on Assets, we will know how much efficiency the company has in utilizing assets for operational activities and can provide information on the size of the company's profitability.

Based on the data processed by the authors, the profitability problems of the four SOE Banks, namely BNI, Mandiri, BTN and BRI from 2009 to 2019 can be seen in the following table:

From the graphic image above can be known the development of soe banking profitability in the period 2009-2019 where it fluctuated, the largest increase in Bank BNI in 2015, followed by Bank Mandiri in 2016.

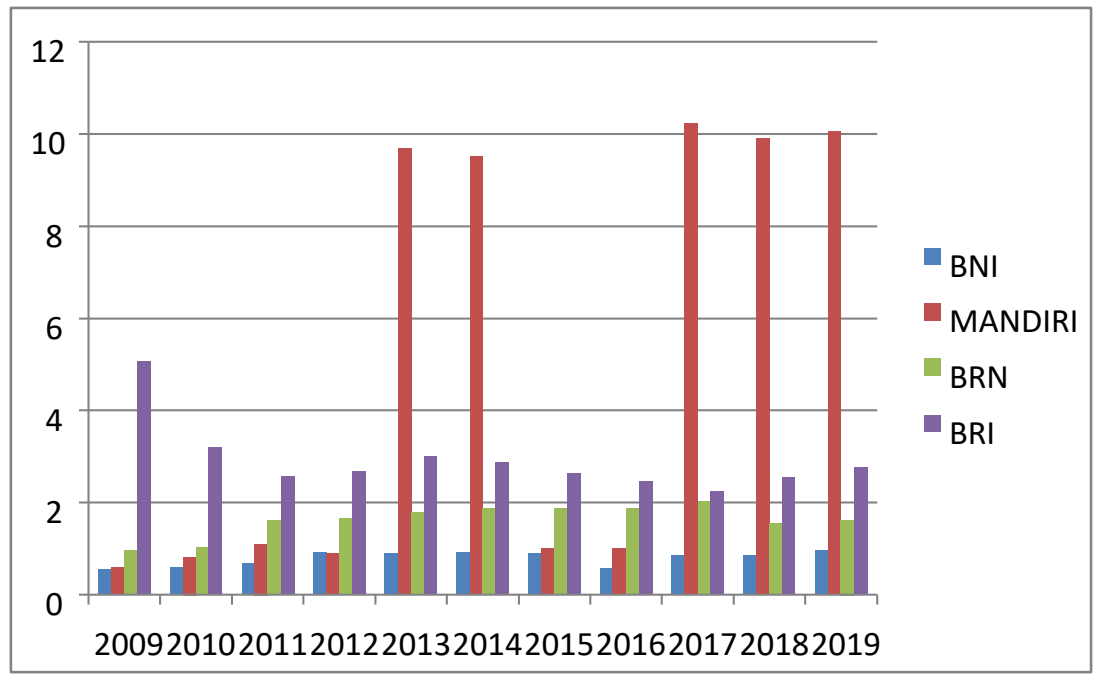

Gambar Grafik 2

Grafik Perkembangan Likuiditas (LDR) Perbankan BUMN Periode Tahun 20092019 
Liquidity (LDR) is a comparison between credit provided with third party funds (Ramadhanti, Marlina, \& Hidayati, 2019). According to (Dendawijaya, 2005) Liquidity (LDR) shows the ratio between the entire amount of credit provided by the bank and the funds received by the bank. LDR states how far the bank's ability to repay depositors' withdrawals by relying on credit provided as a source of ROA. The higher the LDR indicates the more risky the bank's ROA condition, instead the lower the LDR indicates the lack of effectiveness of banks in channeling credit. If the bank's LDR ratio is within the standard stipulated by Bank Indonesia, then the return earned by the bank will increase.

Based on the chart above, the liquidity (LDR) of state-owned banks in the period 2009-2019 has fluctuated, but very significant developments occurred at Mandiri bank between 2013-2014 and 2017 to 2019.

Here is the profit management data on state-owned enterprises banking for the period 2009-2019:

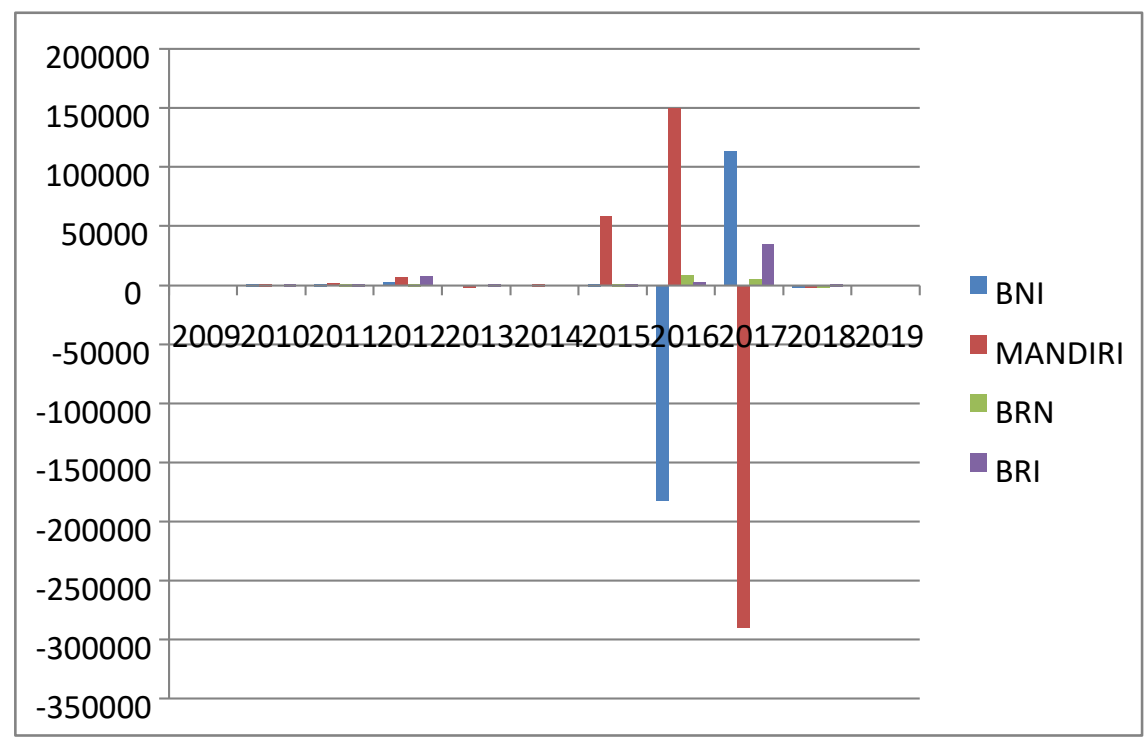

Gambar Grafik 3

Chart of The Development of Soe Banking Profit Management for the Period 2009-2019

Profit management is an agency issue that often occurs in the business environment. The behavior of profit management conducted by management stems from an agency conflict of interest between the owner as principal and the manager as an agent. Principals are interested in achieving ever-increasing profitability so that the maximum rate of return on shares can be achieved. The agent is interested in obtaining maximum contract compensation in order to achieve its prosperity, thus there are two different interests within the company, where each party strives to achieve or maintain the desired level of prosperity, so this will encourage the agent to conduct profit management. If management does not influence or manipulate financial statements, it can be concluded that earnings quality has been of positive value. The reported data is reliable and reliable without interference. Profit management means that the financial 
Analysis of The Effect of Profitability and Liquidity on Income Management Which Impact on Company Value in Soe Banks Registered on Indonesia Stock Exchange Period 2009-2019

statements are correct with the actual condition of a company and will assist stakeholders in predicting the company's future economic performance.

Profit Management can be found in the company's financial statements. The content of information in financial statements is one of the relevant information for the owner as the basis of decision making and assessment of the company. The information is simply visible in the financial ratio that describes the financial condition of the company. The data on the dynamics of financial ratios is generally presented in the following table:

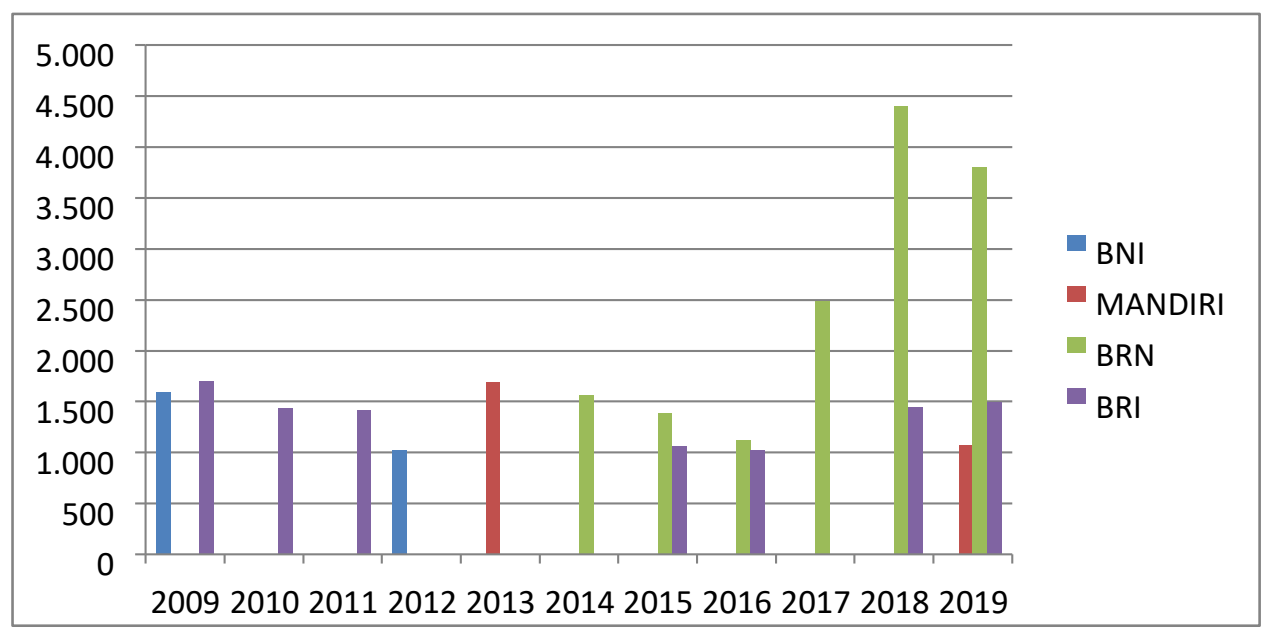

\section{Gambar Grafik 4 \\ Grafik Perkembangan Nilai Perusahaan Perbankan BUMN Periode Tahun 2009-2019}

Based on the background of the above problems as well as the phenomena that occur in state-owned banking companies, the authors are interested to take the following title: "Effect of Profitability and Liquidity on Profit Management Whose Impact on The Value of Companies on State-Owned Banks Listed on Indonesian Stock Exchange Period 2009-2019".

\section{Methods}

According to (Sugiyono, 2017) research methods are a scientific way to obtain data with specific purposes and uses. While according to (Arikunto, 2010). The research method is a way used by researchers in collecting research data. The research method conducted in this study is a descriptive method with a correlational type.

1. Libarary Research

2. Internet Research

\section{Research and Result}

Of the 4 state-owned banks used for research during the period 2009-2019, the next stage is to calculate the variables contained in the research in accordance with the research methods used. Here are the results of the presentation that will be used in this study: 


\section{a. ROA (Return on Assets)}

The data obtained from the company's financial position report on stateowned banks, as well as the presentation of ROA data for the period 2009-2019 are as follows:

\section{Table 1}

Return on Assets at State-Owned Banks for Period 2009-2019

\begin{tabular}{|c|c|c|c|c|c|c|c|c|c|c|c|}
\hline Thn & 2009 & 2010 & $\begin{array}{c}201 \\
1\end{array}$ & $\begin{array}{l}20 \\
12\end{array}$ & 2013 & 2014 & 2015 & 2016 & 2017 & 2018 & 2019 \\
\hline BNI & $\begin{array}{r}0,01 \\
0918 \\
8\end{array}$ & $\begin{array}{r}0,02 \\
4101 \\
4\end{array}$ & $\begin{array}{l}0,0 \\
20 \\
87 \\
84\end{array}$ & $\begin{array}{r}0, \\
02 \\
40 \\
84 \\
3\end{array}$ & $\begin{array}{r}0,018 \\
7332\end{array}$ & $\begin{array}{r}0,028 \\
6017\end{array}$ & $\begin{array}{r}0,041 \\
0199\end{array}$ & $\begin{array}{r}0,020 \\
4511\end{array}$ & $\begin{array}{r}0,022 \\
0174\end{array}$ & $\begin{array}{r}0,0176 \\
067\end{array}$ & $\begin{array}{r}0,02174 \\
06\end{array}$ \\
\hline BRI & $\begin{array}{r}0,027 \\
01\end{array}$ & $\begin{array}{r}0,03 \\
4881\end{array}$ & $\begin{array}{r}0,0 \\
321 \\
09\end{array}$ & $\begin{array}{c}0, \\
03 \\
38 \\
95\end{array}$ & $\begin{array}{r}0,0341 \\
02\end{array}$ & $\begin{array}{r}0,0302 \\
43\end{array}$ & $\begin{array}{r}0,0289 \\
28\end{array}$ & $\begin{array}{r}0,0261 \\
33\end{array}$ & $\begin{array}{r}0,0257 \\
89\end{array}$ & $\begin{array}{r}0,0249 \\
97\end{array}$ & $\begin{array}{r}0,02429 \\
1\end{array}$ \\
\hline BTN & $\begin{array}{r}0,00 \\
8391\end{array}$ & $\begin{array}{r}0,01 \\
3394\end{array}$ & $\begin{array}{r}0,0 \\
125 \\
52\end{array}$ & $\begin{array}{c}0, \\
01 \\
22 \\
06\end{array}$ & $\begin{array}{r}0,0119 \\
09\end{array}$ & $\begin{array}{r}0,0079 \\
24\end{array}$ & $\begin{array}{r}0,0107 \\
73\end{array}$ & $\begin{array}{r}0,0122 \\
28\end{array}$ & $\begin{array}{r}0,0115 \\
83\end{array}$ & $\begin{array}{r}0,0091 \\
63\end{array}$ & $\begin{array}{r}0,00930 \\
6\end{array}$ \\
\hline $\begin{array}{l}\text { MAND } \\
\text { IRI }\end{array}$ & $\begin{array}{r}0,01 \\
8242\end{array}$ & $\begin{array}{r}0,02 \\
0831\end{array}$ & $\begin{array}{r}0,0 \\
230 \\
04\end{array}$ & $\begin{array}{c}0, \\
02 \\
52 \\
41 \\
\end{array}$ & $\begin{array}{r}0,0181 \\
02\end{array}$ & $\begin{array}{r}0,0190 \\
57\end{array}$ & $\begin{array}{r}0,0224 \\
67\end{array}$ & $\begin{array}{r}0,0388 \\
42\end{array}$ & $\begin{array}{r}0,0154 \\
11\end{array}$ & $\begin{array}{r}0,0136 \\
15\end{array}$ & $\begin{array}{r}0,01504 \\
5\end{array}$ \\
\hline
\end{tabular}

Source: Pre-Survey Financial Report Data

\section{b. LDR}

The data obtained from the company's financial position report on stateowned enterprises, as well as the presentation of LDR data for the period 20092019 are as follows:

Table 2

Loan to Deposite Ratio in State-Owned Enterprises Bank Period 2009-2019

\begin{tabular}{llllllllllll}
\hline Thn & 2009 & 2010 & 2011 & 2012 & 2013 & 2014 & 2015 & 2016 & 2017 & 2018 & 2019
\end{tabular}

\begin{tabular}{|c|c|c|c|c|c|c|c|c|c|c|c|}
\hline $\mathrm{BNI}$ & $\begin{array}{l}0,556 \\
462\end{array}$ & $\begin{array}{l}0,583 \\
777\end{array}$ & $\begin{array}{l}0,67 \\
7418\end{array}$ & $\begin{array}{l}0,91 \\
4568\end{array}$ & $\begin{array}{l}0,90 \\
5615\end{array}$ & $\begin{array}{l}0,91 \\
4568\end{array}$ & $\begin{array}{l}0,90 \\
5615\end{array}$ & $\begin{array}{l}0,576 \\
435\end{array}$ & 0,8604 & $\begin{array}{l}0,859 \\
147\end{array}$ & 0,952658 \\
\hline BRI & $\begin{array}{l}5,070 \\
368\end{array}$ & $\begin{array}{l}3,205 \\
552\end{array}$ & 2,55 & $\begin{array}{l}2,67 \\
4079\end{array}$ & 3,00 & 2,88 & $\begin{array}{l}2,63 \\
5681\end{array}$ & 2,461 & $\begin{array}{l}2,250 \\
254\end{array}$ & 2,551 & 2,768384 \\
\hline BTN & $\begin{array}{l}0,953 \\
704\end{array}$ & $\begin{array}{l}1,041 \\
041\end{array}$ & $\begin{array}{l}1,60 \\
8554\end{array}$ & $\begin{array}{l}1,66 \\
5047\end{array}$ & $\begin{array}{l}1,79 \\
1426\end{array}$ & $\begin{array}{l}1,88 \\
3242\end{array}$ & $\begin{array}{l}1,87 \\
4808\end{array}$ & $\begin{array}{l}1,864 \\
098\end{array}$ & $\begin{array}{l}2,020 \\
973\end{array}$ & $\begin{array}{l}1,560 \\
143\end{array}$ & 1,62582 \\
\hline
\end{tabular}


Analysis of The Effect of Profitability and Liquidity on Income Management Which

Impact on Company Value in Soe Banks Registered on Indonesia Stock Exchange

Period 2009-2019

\begin{tabular}{lcccccclllll}
\hline MAN & 0,5794 & 0,818 & 1,10 & 0,88 & 9,68 & 9,50 & 1,01 & 1,004 & 10,22 & 9,893 & 10,05808 \\
DIRI & 6 & 704 & 3042 & 7703 & 1154 & 6995 & 2462 & 322 & 039 & 278 &
\end{tabular}

Source: Pre-Survey Financial Report Data

\section{c. Profit Management}

The data obtained from the company's financial position report on stateowned enterprises, as well as the presentation of Profit Management data for the period 2009-2019 are as follows:

Table 3

Nilai Manajemen Laba

\begin{tabular}{|c|c|c|c|c|c|c|c|c|c|c|c|}
\hline \multirow[b]{2}{*}{ Bank } & \multicolumn{11}{|c|}{ Nilai Manajemen Laba } \\
\hline & 2009 & 2010 & 2011 & 2012 & 2013 & 2014 & 2015 & $\begin{array}{c}201 \\
6 \\
\end{array}$ & 2017 & 2018 & 2019 \\
\hline BNI & $\begin{array}{l}0.0045 \\
39\end{array}$ & $\begin{array}{l}2.061 \\
606\end{array}$ & $\begin{array}{l}193.64 \\
75\end{array}$ & $\begin{array}{l}2435.8 \\
49\end{array}$ & $\begin{array}{l}- \\
0.0003 \\
2\end{array}$ & $\begin{array}{l}0.006 \\
404\end{array}$ & $\begin{array}{l}811.59 \\
32\end{array}$ & $\begin{array}{r}- \\
182 \\
457 \\
\end{array}$ & $\begin{array}{l}113274 \\
.3103\end{array}$ & $\begin{array}{r}- \\
19.74 \\
2\end{array}$ & $\begin{array}{l}0.000 \\
384\end{array}$ \\
\hline $\begin{array}{l}\text { MAND } \\
\text { IRI }\end{array}$ & -0.0256 & $\begin{array}{l}0.525 \\
955\end{array}$ & 1540.12 & $\begin{array}{l}6532.1 \\
62\end{array}$ & $\begin{array}{l}- \\
0.1729 \\
9\end{array}$ & $\begin{array}{l}0.225 \\
719\end{array}$ & $\begin{array}{l}58410 . \\
79\end{array}$ & $\begin{array}{l}149 \\
821 \\
.9 \\
\end{array}$ & $\begin{array}{l}- \\
28946 \\
1.245 \\
\end{array}$ & $\begin{array}{l}- \\
24.7 \\
527\end{array}$ & $\begin{array}{l}0.059 \\
071\end{array}$ \\
\hline BRN & $\begin{array}{l}- \\
0.0276 \\
7\end{array}$ & $\begin{array}{l}0.091 \\
736\end{array}$ & $\begin{array}{l}104.76 \\
64\end{array}$ & 626.487 & $\begin{array}{l}0.0094 \\
79\end{array}$ & $\begin{array}{l}- \\
0.01 \\
177 \\
\end{array}$ & $\begin{array}{l}1073.5 \\
69\end{array}$ & $\begin{array}{l}821 \\
3.8 \\
82 \\
\end{array}$ & $\begin{array}{r}5107.01 \\
25\end{array}$ & $\begin{array}{l}- \\
2.82 \\
858\end{array}$ & $\begin{array}{l}0.009 \\
323\end{array}$ \\
\hline BRI & $\begin{array}{l}0.0009 \\
15\end{array}$ & $\begin{array}{l}1.052 \\
973\end{array}$ & $\begin{array}{l}365.18 \\
33\end{array}$ & $\begin{array}{l}7137.3 \\
86\end{array}$ & 0.17198 & $\begin{array}{r}0.049 \\
46\end{array}$ & $\begin{array}{l}1373.0 \\
22\end{array}$ & $\begin{array}{l}251 \\
3.5 \\
04 \\
\end{array}$ & $\begin{array}{l}34345 \\
64634\end{array}$ & $\begin{array}{l}22.50 \\
335\end{array}$ & $\begin{array}{r}0.054 \\
89\end{array}$ \\
\hline
\end{tabular}

Source: Pre-Survey Financial Report Data

d. Company Value

Table 4

Company Value in State-Owned Enterprises Bank Period 2009-2019 $200920102011201220132014 \quad 201520162017 \quad 2018 \quad 2019$

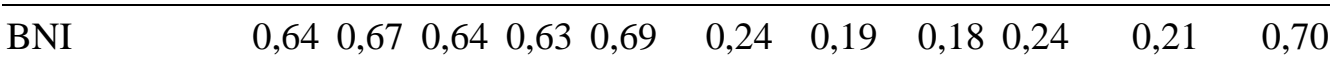

\begin{tabular}{llllllllllll}
\hline MANDIRI & 0,69 & 0,76 & 0,67 & 0,99 & 0,84 & 0,73 & 0,85 & 0,85 & 0,96 & 0,6 & 0,54
\end{tabular}

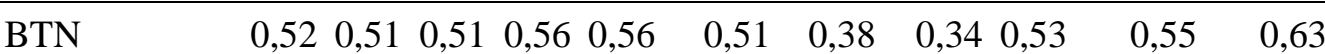

\begin{tabular}{llllllllllll}
\hline BRI & 0,37 & 0,41 & 0,59 & 0,6 & 0,48 & 0,52 & 0,55 & 0,52 & 0,47 & 0,5 & 0,41
\end{tabular}

Source: Pre-Survey Financial Report Data

e. Data Analysis

1. Descriptive Statistical Analysis

Descriptive statistical analysis was performed to provide an overview or descriptive of the variables used in this study. Descriptive statistical testing is performed to provide an explanation of the minimum value, maximum value, 
standard deviation value and average value of each variable. The variables used are ROA, LDR and Profit Management from.

\section{Conclusion}

Based on the research, the conclusions that can be drawn in this study are ratio of profitability, liquidity, profit management and company value to state-owned banks. The sample used consists of 4 data of state-owned banks in 2009 to 2019, can be summed up as follows:

A. The results showed that ROA partially had no effect on Profit Management, at stateowned banks from 2009 to 2019. This is evidenced by using a t test that produces a T-statistic ROA value of $0.329837<\mathrm{t}$-table 2.012895 with a prob significance value of $0.7430>0.05$, then $\mathrm{H} 1$ is not proven (rejected).

B. The results showed that LDR partially had no effect on Profit Management at stateowned banks for the period 2009 - 2019. This is evidenced by using a t test that yields an LDR t-statistic value of 0.373496 < t-table 2.012895 with a prob significance value of $0.7105>0.05$, then $\mathrm{H} 2$ is rejected.

C. The results showed that ROA and LDR simultaneously had an effect with Profit Management at state-owned banks from 2009 to 2019. This is evidenced by using test $\mathrm{F}$ which produces an F-statistic value of $45082.10>\mathrm{F}$ table (2.80684) and a significance value of $0.0000<0.05$, then $\mathrm{H} 4$ was proven (received). 4 . The results showed profit management had a t statistic $<\mathrm{t}$ table $(322.4090<2.012895)$ with a significance value of $0.0000>$ a level of significance of 0.05 . These results show that profit management affects the Value of the Company.

The recommendations that the authors can provide in connection with this study are Theoretical Advice, namely For Students, For Authors, as a means to broaden insights and add references to financial management especially about financial performance so that it can be utilized for future authors. For Other Researchers, in the next study can use a more variable financial ratio because there are still many variables that can be used. Practical Advice, For Companies, It is expected to pay more attention to the expectation of corporate data, because it is a challenge for public companies and supervising institutes to ensure the availability of financial report data which is an obligation for public companies to publish to the public as the use of financial statements, so that for further research is expected in obtaining completeness of data and accessing data can be done easily. For Investors and Prospective Investors, the results of this research can provide information to investors and potential investors about the financial condition of a company and know the viability of a company, so that it can be used as a consideration material before deciding to invest. 
Analysis of The Effect of Profitability and Liquidity on Income Management Which

Impact on Company Value in Soe Banks Registered on Indonesia Stock Exchange

Period 2009-2019

\section{BIBLIOGRAPHY}

Arikunto, Suharsimi. (2010). Prosedur Penelitian Ilmiah. In Rineka cipta, Jakarta.

Defri, Gunawan. (2012). Pengendalian Intern Pemberian Kredit Pada Bank Perkreditan Rakyat Lumbung Pitih Nagari (Bpr-Lpn) Limaumanis Padang. Universitas Andalas.

Dendawijaya, Lukman. (2005). Manajemen perbankan.

Dewi, Gusti Ayu Pradnyanita, \& Sari, Maria M. Ratna. (2015). Pengaruh insentif eksekutif, corporate risk dan corporate governance pada tax avoidance. E-Jurnal Akuntansi, 13(1), 50-67.

Gerdes, Martin, Trinugroho, Yohanes Baptista Dafferianto, Fensli, Rune, \& Lilletunsvei, Jon. (2013). Aspects of Standardisation for Point-of-Care Solutions and Remote Home Monitoring Services. Holistic System Design For Distributed National Ehealth Services, 129.

Husnan, Pudjiastuti Enny, \& Pudjiastuti, Enny. (2012). Manajemen Keuangan Edisi Keenam. Jakarta: UPP STIM YKPN.

Marelli, Benedetto, \& Omenetto, Fiorenzo G. (2015). Cashmere-derived keratin for device manufacturing on the micro-and nanoscale. Journal of Materials Chemistry C, 3(12), 2783-2787.

Ramadhanti, Chairunnisah, Marlina, Marlina, \& Hidayati, Siti. (2019). The effect capital adequacy, liquidity and credit risk to profitability of commercial banks. Journal of Economics, Business, and Government Challenges, 2(1), 71-78.

Subramanyam, K. R., \& Wild, Jhon J. (2013). Analisis Laporan Keuangan, edisi kesepuluh. Jakarta: Salemba Empat.

Sudiyatno, Bambang, \& Suroso, Jati. (2010). Analisis Pengaruh Dana Pihak Ketiga, BOPO, CAR dan LDR terhadap Kinerja Keuangan pada Sektor Perbankan yang Go Public di Bursa Efek Indonesia (BEI)(Periode 2005-2008). Dinamika Keuangan Dan Perbankan, 2(2).

Sugiyono. (2017). Metode Penelitian Kuantitatif, Kualitatif, dan R\&D. Bandung: Alfabeta.

Wibisono, H. Koento. (2013). Pariwisata Dalam Perspektif Ilmu Filsafat (Sumbangannya bagi Pengembangan Ilmu Pariwisata di Indonesia). [Yogyakarta]: Universitas Gadjah Mada. 